\title{
Radical Cultural Specificity in Translation
}

DOI:

10.1075/tis.18021.str

\section{Document Version}

Accepted author manuscript

Link to publication record in Manchester Research Explorer

\section{Citation for published version (APA):}

Strowe, A. (2020). Radical Cultural Specificity in Translation. Translation and Interpreting Studies.

https://doi.org/10.1075/tis.18021.str

\section{Published in:}

Translation and Interpreting Studies

\section{Citing this paper}

Please note that where the full-text provided on Manchester Research Explorer is the Author Accepted Manuscript or Proof version this may differ from the final Published version. If citing, it is advised that you check and use the publisher's definitive version.

\section{General rights}

Copyright and moral rights for the publications made accessible in the Research Explorer are retained by the authors and/or other copyright owners and it is a condition of accessing publications that users recognise and abide by the legal requirements associated with these rights.

\section{Takedown policy}

If you believe that this document breaches copyright please refer to the University of Manchester's Takedown Procedures [http://man.ac.uk/04Y6Bo] or contact uml.scholarlycommunications@manchester.ac.uk providing relevant details, so we can investigate your claim.

\section{open 2 Access}


This is a manuscript of an article accepted for publication by Translation and Interpreting Studies. (Accepted 9 December 2019).

\title{
Radical cultural specificity in translation
}

\section{Anna Strowe, University of Manchester}

\begin{abstract}
Most existing discussions of cultural specificity in translation presume that although translation may be difficult, the meaning of culturally specific terms is at least known. This article considers the possibility of "radical cultural specificity," in which the meaning of the item is inaccessible to the reader or translator and no native participant in the source culture is available to advise. Based on the concepts of culturally specific items from the work of Javier Aixelá and radical translation from the work of W.V.O. Quine, I develop the notion of radical cultural specificity using examples from medieval Celtic literature, highlighting the role of knowledge and lack of knowledge in interpretation and translation. The concept is then briefly applied to science fiction or speculative fiction as well, suggesting that these concerns are not merely the province of scholars of historical literature.
\end{abstract}

\section{Keywords}

culturally specific items, radical translation, medieval literature, science fiction, cultural knowledge 


\section{Radical cultural specificity in translation}

Conversations about cultural specificity in translation generally focus on issues of asymmetry between cultures: how to translate into a target language a concept, object, or term that exists in the source culture but not in the target culture. Some texts, however, present additional problems, in the form of concepts, objects, or terms that are simply unknown. This problem is to be encountered particularly in translations of ancient or medieval texts, where external resources may not be available to help figure out the meaning of particular items. This paper explores the phenomenon of such concepts, and the issues with their translation, drawing literature in translation studies on linguistics, cultural specificity, and cross-temporal translation, as well as some examples from medieval literature. It proposes them as a kind of radical cultural specificity that has its own set of challenges and possible solutions in translation.

In order to do this, I move between a few different articulations of the problem of lack of symmetry between cultures and lack of knowledge about meaning. As a starting point, I take the idea of culturally specific items (CSIs) and the pragmatic (as opposed to philosophical) approach to them that is taken by Javier Franco Aixelá (1996), drawing as well on some articulations of cultural and historical difference from James Holmes (1994a, 1994b). I then connect these issues to W.V.O. Quine's idea of "radical translation" (1960: 28) and to Maria Tymoczko's use of it to discuss the indeterminacy of meaning in translating dead languages (1999: chapter 5). My use of these concepts though is less philosophically oriented than either of these approaches, aimed as it is at the delineation of radical cultural specificity rather than analysis of the forms of linguistic epistemology or the distinction between comprehension and translation. I then explore the triangulation of meaning that is sometimes possible in such cases, essentially the levels of not- 
knowing. Finally, I move into the intersection between lack or impossibility of background knowledge as a form of radical cultural specificity and linguistic and literary creativity as a source of it. Throughout these sections, I draw on examples from medieval Celtic literatures (Middle Welsh and Old Irish), and at the end, bring in contemporary science fiction as a genre of interest in this area.

Thus, the goal is not to continue the debate on Quine's radical translation or explicitly to expand Tymoczko's notion of the epistemological progression of a translation of a dead language, although I will draw on both of these. I am less concerned with the epistemology of unknowability than with the pragmatics of the unknown. My aim is also not to try to posit a set of translation problems and solutions, as Aixelá's work did for culturally specific items more in general, although reference will also be made to these. It is to explore the ways in which this form of cultural specificity can manifest itself, what types of solutions it perhaps excludes, and where it might leave us as readers and translators.

\section{What we know, and what we don't know}

Aixelá starts with the presumption that "each linguistic or national-linguistic community has at its disposal a series of habits, value judgements, classification systems, etc. which sometimes are clearly different and sometimes overlap" (1996: 53), and then continues by discussing translation strategies that can be used to mediate instances of "cultural asymmetry" and difference. He notes as well that historical distance is a variant of cultural diversity, and notes in Anglophone translation the tendency towards a strategy that tends to favor the target culture, and in other lingua-cultures a tendency to assume familiarity with Anglo-American cultural items (1996: 54-55), drawing on Lawrence Venuti's data and analysis (1992: 5; see also Venuti 1995: chapter 1). 
Aixelá further draws on James Holmes' discussions of historical difference (Holmes 1994a), distinguishing between the dimensions of language and the socio-cultural situation. Where Aixelá's primary concern is with what Holmes terms the socio-cultural dimension, Holmes notes that the same large-scale strategies that relate to the socio-cultural dimension exoticizing vs. naturalizing and historicizing vs. modernizing — apply as well to the use of language and to the intertextuality of a work (Holmes 1994a; see also Holmes 1994b). Holmes suggests that these choices can be visualized with a graph where the horizontal axis runs from exoticizing on the left to naturalizing on the right, and from historicizing to modernizing top to bottom. The upper left quadrant is thus the realm of retention (of historicity and cultural otherness) and the lower right of recreation (of modernization and adaptation).

In order to make such an analysis, however, we must note something that in other circumstances might go without saying. To deliberately choose any of these strategies, one must understand the linguistic, intertextual, and socio-cultural historical and culturally-specific terms. This is not, however, always the case for translators of historical texts, not because of any inadequacy on the part of the translators, but because of the limits of what is known about the socio-cultural situation, the language, or the intertextual references. Medieval and ancient cultures are not the same as those that may have grown out of them, and certainly not the same as those that developed in other places or with other influences. The otherness of foreign cultures is not necessarily further from us than the otherness of history, and the otherness of history (of our "own" cultures) is sometimes even more shocking because we presume some kind of familiarity based on descent that is not always present.

A clear and concise articulation of the translation problem this causes comes from Craig Davis, a scholar of medieval Welsh literature, in a talk at Smith College on his work translating a 
poem called Preiddeu Annwn (The Spoils of Annwn; pronounced “Ah'-noon”). The poem tells the story of a voyage to some kind of otherworld made by King Arthur, involving a rescue, a magical cauldron, and the death of most of his men. Of the entire poem, Roger Sherman Loomis has commented that "[its] obscurity is due in part to the antiquity of the language... the corruption of the text... [and] the highly allusive nature of much bardic composition, which assumed familiarity with oral... traditions now in large measure lost" (1941: 887-888). In the fifth stanza, the poet describes a group of people (it is unclear who, but perhaps the residents of the otherworld) in terms of their lack of knowledge about the poet's own world: about Arthur or religion for example (in Davis' translation; Davis 2005: 132). In discussing his translation and the difficulties of this poem, Davis quoted the fifth line of the stanza, and added his own commentary: “'They do not know about the speckled ox with its thick neck-rings'... and neither do we."1

Even the rigorous analysis of other literary materials (across Welsh, Old Irish, French, and Latin) and intertextual associations carried out by Loomis (1941) do not help with this; indeed, Loomis only translates and annotates the first four stanzas. Of the rest, he remarks that "in the present state of our knowledge it does not seem possible to offer any satisfactory translation of the last three of the seven stanzas, or to hazard any remarks as to their content

\footnotetext{
${ }^{1}$ The line that Davis presents as his source text is as follows:

Ny wdant wy yr ych brych bras y penrwy (Davis 2005: 130)

See also the translation of Marged Haycock (2007: 437), whose translation differs somewhat, but refers to "those who know nothing of the Brindled Ox, with his stout collar..." The lack of knowledge is similar, even if the identity of the people who do not know may be different. This same ox is also mentioned in the Trioedd Ynys Prydein (the Triads of the Island of Britain) as one of the three chief oxen of the island (Bromwich 2014: 124; triad 45), but without adding any helpful information.
} 
except that stanzas 5 and 6 allude to the same calamitous expedition of Arthur as do the first four..." (1941: 888).

This is not the fault of the translator, but rather an example of what I am terming "radical cultural specificity", in which the pragmatic meaning of the utterance is not only culturally specific but also inaccessible. While we may be able to translate and understand each of the words of the sentence (barring the potential and even perhaps likely event that some of them are used in metaphorical ways), the loss of cultural knowledge means that any meaning past that level is also lost. We might complicate this even further by observing that sometimes the meanings of the words themselves are not agreed on, and that without a guiding pragmatic principle that allows interpretation of metaphor and other rhetorical devices, even the semantic value of an utterance may be difficult to settle on.

In this case, it is impossible even to say what relationship the phrase at hand has to the "common expressions" that Aixelá identifies as one of the two categories of culturally-specific items, alongside proper nouns, having to do with "the world of objects, institutions, habits and opinions restricted to each culture" (1996: 59). In fact, we cannot even say with any particular certainty which part of the utterance (or the whole thing) is culturally specific: for example the existence of a specific ox with religious or cultural implications identifiable by those characteristics. Is it the speckles (in Davis' translation) or the neck-rings that are important? Or are both of these merely identifiers, and it is the whole ox or its biography that matters? Does it refer metaphorically or metonymically to an agricultural or a religious matter? 


\section{On radical specificity and untranslatability}

This discussion has connections to the concept of radical translation, and the concept of indeterminacy that Quine posited in connection to it. ${ }^{2}$ Quine's radical translation is a thoughtexperiment of sorts, in which we imagine the resources and processes of a linguist engaged in producing a translation manual between English and a previous completely unknown language. In Quine's scenario, there is no bilingual person (or chain of bilingual people) available to help, only (monolingual) native speakers of the non-English language. Quine refers to translation from this language, which is the ultimate goal of the process, as "radical translation" (1960: 28). He illustrates some of the issues involved with the now-famous example of the word or utterance "gavagai," which may or may not mean "lo, a rabbit."

What renders Quine's scenario radical is the absence of resources, what Mannheim (2015: 200) refers to as "shared scaffolding," apart from those available in the set of interactions that the linguist has with the new language and its speakers. The linguist thus has to rely on their own logic and intuition, combined with the ability to prompt responses in a variety of observed situations. Does the speaker say "gavagai" when a rabbit goes past? When two rabbits go past? If the linguist points to a brown rabbit as compared to a white rabbit? If rabbit stew is served for dinner? The linguist, says Quine, is left comparing what their own reactions would be to their hypothesized translation (yes, a rabbit, no, not a rabbit), with what they interpret to be affirmations or denials on the part of the native speaker of this other language. The overall set of such situations combined with the reactions is what composes the "stimulus meaning" of "gavagai" (and "rabbit").

\footnotetext{
${ }^{2}$ The discussion appears in a 1959 article and then in expanded form as a chapter of Word and object (Quine 1960).
} 
Further discussions have problematized Quine's experiment and its conclusions from linguistic and philosophical standpoints, and it is far beyond the scope of this paper to contend with the full articulation of Quine's radical translation. ${ }^{3}$ What I want to do is draw out a few key elements that can contribute to a vision of a similarly "radical" notion of cultural specificity.

Turning to our medieval literary example, we find certain parallels. There is nobody who speaks both Middle Welsh as a native speaker and English who can inform us. In fact, there is nobody alive who can be consulted as a Middle Welsh native speaker at all. Rather than a live interaction in which stimuli can be presented and stimulus meaning teased out, we have a text, located within a set of texts, in which certain static formulations exist (and some variations as well, among copies of the same text). We have nobody of whom we might enquire, in a different situation, "Would this also be an appropriate time to talk about the speckled ox?"

In other ways, however, we are beyond the initial stages of Quine's experiment in radical translation. We have access to already-assembled "manuals of translation" (dictionaries), and we know that there are relationships between Middle Welsh language and culture and modern Welsh language and culture, where Quine presumed complete separation. So we know what the words mean individually. We are relatively certain that a native Middle Welsh speaker would assent to the question "ych?" when confronted with something we would recognize as an ox, and to "brych?" when looking at a particular pattern of coloration.

Not all meaning, however, comes from the immediately observable in a situation. Quine describes this idea with the rabbitless example of the word "bachelor": the face of a particular person may prompt this utterance, but the meaning of it relies not on something readily

\footnotetext{
${ }^{3}$ For a concise and relatively comprehensible survey of these discussions, see Wright (2017).
} 
observable, but on prior knowledge about that person. The phrase "they do not know about the speckled ox with its thick neck-rings" suggests a similarly un-observable aspect that is escaping, not a linguist in this case, but the people of this other world, as well as the translator. And as with rabbits, so with oxen. We do not know what is even relevant here: the speckling, the animal itself, the thickness of the neck-rings, the neck-rings themselves. And we do not know what it is about them that we do not know. But here, unlike Quine's linguist, we cannot ask or test. As Tymoczko (1999: 153) observes regarding Old Irish, "there is no pool of native speakers to enlighten us about those meanings within the framework of the language itself, no pool of native speakers to teach us Old Irish.” If the concept is not explained elsewhere using words and concepts we are able to learn in other ways, it remains indeterminate. Tymoczko (1999: 153 ff.) moves from this towards an understanding of translation as a fundamental process of language learning for dead languages, but we can also understand it as producing a particular kind of lack of knowledge, which itself produces a particular kind of untranslatability.

This kind of radical cultural specificity is untranslatable in a very fundamental sense that differs from current discussions of "untranslatability" in the context of translation and philosophy. Emily Apter (in Cassin 2014: vii) describes an untranslatable as "loosely... a term that is left untranslated as it is transferred from language to language... or that is typically subject to mistranslation and retranslation.” A radically culturally specific term can indeed be left untranslated as it is transferred, but not, I would argue, for the same reasons that the untranslatables of philosophy, for example, are left untranslated. We are not speaking here of a term that is too complex or too precise to be rendered in any definitive way (as far as anything can be said to be rendered in a definitive way in translation), where the borrowing of a term is commonplace because the readership comes to understand that the term is so specific that it can 
only be translated with itself, or where successive re-translations each attempt to get at differently understood cores or concepts contained within it. Barbara Cassin (2014: xvii) describes this (in Michael Wood's translation of her introductory remarks) by suggesting that "the untranslatable... is what one keeps on (not) translating." Re-translations and reinterpretations for radical cultural specificity may also exist, as may the borrowing or calque of the original term, but they do so not to capture other elements of what the term is actually known to mean, but to express different versions of what it might possibly mean. Rather than the challenge of a lack of precision in translation or what Apter describes as an instability of meaning (in Cassin 2014: vii), radical cultural specificity presents the challenge of a more or less absolute lack of knowledge. Cassin (2014: xx) uses the metaphor of cartography to talk about the network of relationships that an untranslatable term has; radical cultural specificity is the area on such a map that is marked "here be dragons."

\section{What we partly know}

We are not always completely in the dark about radically culturally specific items, however. In the Old Irish tales of the Ulster Cycle, there appears a number of times some kind of feat or trick that is or can be performed by a warrior, and which is generally translated as something like the "salmon leap" or the "warrior's salmon leap". The phrase in Old Irish is "ich n-erred"; broken down by word, "ich" or "ích" is the genitive or accusative singular of "eó" (salmon), and "erred" is the genitive of "eirr" (chariot-fighter or champion). ${ }^{4}$ The " $\mathrm{n}$ " preceding

\footnotetext{
${ }^{4}$ It is perhaps to be noted that the "ich n-erred" is usually discussed as such, even though the phrase is in the accusative or genitive, rather than the nominative. It is possible that it only ever appears in these forms as a phrase.
} 
"erred" is a product of the preceding accusative form, which requires the nasalization of the following word. Literally, it means something like "salmon of the warrior(s)." As with the ox, we have established by various other processes what each individual word means, but the whole phrase is still less than transparent.

Tymoczko (1999: 155) notes, also with regard to Old Irish, that "the meanings of most of the words are sufficiently well established" that we can move from "accessible elements" to "a preliminary interpretation or set of alternative interpretations of the text as a whole." Indeed, this can be done here. The phrase appears a number of times in the existing corpus, although sometimes in slightly different forms and contexts depending on the manuscript. ${ }^{5}$ In several of these, it is the object of some form of the verb "foceird," which has a variety of meanings including to perform, execute, or wage, according to the Dictionary of the Irish language (DIL; see Electronic dictionary of the Irish language, n.d.), the authoritative historical dictionary of medieval Irish. ${ }^{6}$ Indeed, the entry for the accusative form "íach" in the DIL for "eó" describes it as being used especially in the phrase "ích n-erred," with "foceird" as a suggested likely verb. The ich n-erred appears with various forms of the verb "foceird" including active verbal forms and the form "cor", which is known as the verbal noun (the act of performing, executing, waging). In one case (example $1^{7}$ ), it appears with two forms of the verb. It also appears with the

\footnotetext{
${ }^{5}$ The set of tales in which it occurs are the Aided Óenfir Áife (Death of Áife's Only Son; see van Hamel 1978 and Meyer 1904), the Táin Bó Cúailnge (Cattle Raid of Cooley; see Strachan and O'Keeffe 1912 and O'Rahilly 1967), two versions of the Tochmarc Emire (The Wooing of Emer; see Meyer 1888 and 1890 and van Hamel 1978), and the Fled Bricrenn (Bricriu's Feast; see Windisch 1880).

${ }^{6}$ It is meaning $1 \mathrm{i}$ as listed in the dictionary.

${ }^{7}$ All examples are included in the Appendix, both in Old Irish and in indicative translation.
} 
verbal noun "imbert" (act of using, handling a weapon, performing) in one version of the Táin bó Cúailnge (example 8). At other times, it appears as part of a list of feats, many of which include the word "cles" (feat) in their name (examples 9-10), and once it occurs following the preposition "cen" (without), to describe how a talented young man accomplished an extraordinary feat without even resorting to this impressive trick.

From these collocations, we begin to assemble our understanding of what might be an otherwise opaque phrase. Unlike the speckled ox, the ich n-erred appears in sentences that give clues to what it might be. It is something that is performed or done. It makes sense in a list of things that are more clearly identified using a word that is less opaque, "cles", suggesting that the ich n-erred too may be a kind of feat, even though its name does not include that same word. We thus have an idea at least of the superordinate category to which it belongs. We also know a little bit about what it might be from some of the rest of the context. The feat is described in spatial terms as being something that can be performed over or above a chariot (example 2) or across (which would imply over) walls or earthworks (example 3). It seems to cover distance from where the person performing it is to other places (examples $4,5,7$ ), or simply up (example 6). The translator can thus surmise some kind of leap — a motion that can overtop a rampart, bring one from one end of a bridge into the middle, or simply go up from the starting point.

The idea that such a leap might be associated with salmon, a fish known for its leaping, does not stretch the imagination too far, and indeed, many of the translators choose to specify by describing the feat as the "heroes' salmon leap" (Meyer 1888: 72), "hero's salmon leap" (Meyer 1888: 232), “chariot-chief’s salmon leap" (Meyer 1890: 449 and 453), “champion's salmon leap” (van Hamel 1978: 173), or "heroic salmon-leap" (Kinsella 1969: 128). 
We have extratextual (although not contemporary) resources as well, not in the form of the kind of unbroken scholarly tradition that Tymoczko notes is not available for Old Irish (1999: 152), but in the form of hints in later but culturally-related dialects or traditions. That is to say, the "salmon leap" appears elsewhere to confirm the idea that this might be what was being aimed for by the Old Irish name of the feat. In a discussion of salmon in the Historie of Scotland, written in Latin by Jhone Leslie and translated into Scots by Father James Dalrymple in 1596 (Leslie 1888: 51), the reader is informed that the salmon makes impressive leaps to return upriver, "quhairfor, ony Lope thocht wondirful, is compaired with the Salmonte, and commounlie called the Salmont lope" (wherefore, any Leap thought wonderful, is compared with the Salmon, and commonly called the Salmon leap). ${ }^{8}$

For an illustration of a later interpretation of a salmon leap, we might turn to a short genealogical account from 1733 of the Birnie and Hamilton families of Broomhill, in Scotland (Birnie 1838). Of one of the Birnies, we are told the following:

Master William, whose picture wee have, was of a good personage, and so agile, that, preferable to many in those dayes, he would leap the salmond's leap, by streaching himself upon the grasse, leaping to his feet, and again throwing them over his head. (Birnie 1838: 5) $)^{9}$

\footnotetext{
8 "Lope" is defined by the Dictionary of the Older Scottish Tongue (up to 1700) as a variant of "lowp", meaning the act of leaping. The Dictionary is available through the online Dictionary of the Scots Language (n.d.).

${ }^{9}$ The contemporary magic of the internet permits me to suggest that Master William's salmon leap might today be called a "kip-up backflip", examples of which can be viewed on YouTube.
} 
Another version of the leap is mentioned by Matthieu Boyd (2016), who presents a description of a "salmon flip" from British Columbia performed by an Irish logger:

Lying with his stomach on the floor, arms straight out from his shoulders, he could contract his muscles violently enough to flip himself off the floor and clap his hands together underneath his body while still in the air, before he hit the floor again! This without using arms and legs to assist him. (Hammond 1999, quoted in Boyd 2016: 43)

It is difficult to see how either of these particular versions of a salmon's leap might propel the Irish hero Cú Chulainn over three sets of fortifications or over a bridge, but fortunately Leslie and Dalrymple's description means that not only these versions, but "ony Lope thocht wondirful" might acquire this appellation.

However, Tymoczko's process of using already-understood stretches of text as well as outside knowledge about cultural traditions, which she also observes can be recursive, has a hypothetical end-point that Quine's radical translator does not. While the radical translator in Quine's thought experiment could theoretically keep asking questions indefinitely to try to refine their understanding of "gavagai," the resources (texts, cultural artifacts) that form the basis of understanding for Tymoczko's process are finite. At a certain point, there is simply no additional surviving information that can be gotten and applied. 


\section{On strategies}

In each of the preceding cases, the translator is confronted with transferring a meaning that is not contained only in the observable, stimulus meanings of the individual words, but which requires outside knowledge of a kind that is at least partly inaccessible to us. Barring the discovery of a new Middle Welsh text explaining what is significant about the ox, or a $9^{\text {th }}$ century diagram of someone performing the ich n-erred, we will not progress beyond in the first case a literal translation of the individual words and in the second a reasonably solid hypothesis that the phrase speaks of some kind of acrobatic leap. The cultural specificity of these ideas is obvious — clearly these things meant something — but indeterminate to some extent — we either do not know at all or do not know exactly what that something might be.

As such, the strategic options available are more limited than those included in previous typologies of translation solutions for culturally-specific items, as well as typologies for translating idiomatic expressions, which these may also be. Aixelá (1996) suggested a set of translation solutions divided into the categories of conservation and substitution. Many of his strategies, however, rely on an understanding of the source text item that we do not have in these cases of radical cultural specificity. The translator of Middle Welsh cannot provide an extra- or intratextual gloss (conservation) or use synonymy, universalization, or naturalization (forms of substitution), because they do not know what information needs to be provided in a gloss, or with what specific or general phrase, or target culture phenomenon to replace the source text phrase. Attempts could range from the merely unenlightening to the absurd, all unpoetic:

"They do not know about the speckled ox with its thick neck-rings, symbolic of some unknown religious or cultural aspect of King Arthur's court" (intratextual gloss) 
"They do not know about the animal we sacrifice as part of a religious ceremony" (synonymy combined with speculation)

"They do not know about our cultural practices" (universalization with slightly less speculation)

"They do not know about John Deere tractors/crucifixes" (naturalization with implausible levels of speculation)

We cannot effectively substitute or explain because we lack the knowledge of what must be substituted or explained. We are left with a limited range of options: repetition of the text in its original form ("Ny wdant wy yr ych brych bras y penrwy"), translation just of the words themselves ("They do not know about the speckled ox with its thick neck-rings"), or deletion (in which case large sections of the poem might end up being left out). Thinking of it as an idiom provides no real help. If there is a Middle Welsh phrase in which "to know of the speckled ox..." has some specific meaning, we are just as in the dark as before, and are limited to leaving the words translated but the meaning opaque, as we can neither explain the idiom nor substitute an equivalent in the target language.

In the case of the ich $n$-erred, we have a few additional options, largely because of the information we can gather from context and from the existence of a later idiomatic phrase that we can understand: the salmon leap. Yet the translator is still limited by incomplete knowledge. We cannot quite describe the precise action that is taken, as a synonymous replacement for the 
phrase, nor can we necessarily come up with a modern target equivalent. In the examples listed above of translations of ich n-erred, the translators rely on what Aixelá (1996: 61) calls "linguistic (non-cultural) translation": the translation of the words themselves ("salmon" and "warrior," "hero," or "chariot-chief"). They add the word "leap," which might be seen as an explicitation that comes as much from the surrounding text as from the phrase itself.

Elsewhere, a few other choices appear. Meyer, who as noted above does use linguistic translation in some places, uses deletion in others, as with his translation of "Aided Óenfir Áife" (The Death of Áife's Only Son; example 11). The broader passage in that text is the son listing his accomplishments in order to tell the warrior who has come to confront him that he should turn back; it is poetic and very difficult to parse. Rather than translate the whole thing, Meyer deletes that section, preserving only the command to turn back, and the idea that even if the warrior were as strong as a hundred men, he would not be able to stop the young man.

Cecile O'Rahilly, instead, chooses repetition, leaving all of the names of feats, including the ich n-erred, in Old Irish, in italics: "Early on that day Cú Chulainn betook himself to his feats. These are all their names: uballchless, fóenchless, cless cletínech,... ích n-errid, cor ndelend..."(O'Rahilly 1967: 189, italics in the original). It is not particularly enlightening, although at least because of the previous sentence, the reader knows that they are all feats of some kind.

\section{What we invent}

The beauty of language, and of translation, however, is that no set of strategies completely exhausts all of our options. A final example will illustrate the creativity of translation 
in the face of radical CSIs (or idioms) and suggest that in the end, full comprehension is not always necessary.

Another strange item from the Ulster Cycle, also related to the hero Cú Chulainn, is something that happens to him in battle: "ríastrad" or "distortion." 10 The verb is "ríastraid" (to contort or distort), generally used as an impersonal ("it distorted") with Cú Chulainn as the object of the preposition "imm" (around, upon) (it distorted around him). But unlike the ich nerred, the riastrad is described, several times, rather explicitly. Among the things that happen as part of Cú Chulainn's distortion: one eye gets sucked into his head so far that a crane could not peck it out, and the other dangles out on his cheek; his hair spikes up so that if an apple fell on it, the hair would spear it and the apple would not hit the ground; his muscles all twist around inside him; his whole body appears to bulk up. ${ }^{11}$

Here we have enough of a description to identify similar occurrences in other cultures: the berserkers in medieval Scandinavia, the Hulk in contemporary Marvel comic books and movies. ${ }^{12}$ We are not without parallels, then, and because of this description we have some idea of what is being described with this term. Aixelá's strategies can all perhaps be employed, to various effects. But one of our parallels is historical (berserkers), and another may not be quite what we want (is "hulking out” in Marvel comic terms really the same as Cú Chulainn's distortion?).

Thomas Kinsella's choice was to translate "ríastrad" with "warp-spasm": "The first warpspasm seized Cú Chulainn" (1969: 150). What is a "warp-spasm"? Perhaps something as strange

\footnotetext{
${ }^{10}$ It appears in example 4 in the appendix.

${ }^{11}$ For more complete descriptions and translations, see Kinsella (1969: 150-153) and O’Rahilly (1967: 201-202).

12 See for example Henry (1982), van Zanten (2007: 46-49), and Moore (2009).
} 
and mysterious as a "ríastrad." Certainly something that is not linked with another medieval culture, or with Marvel comics. Post-Star trek, which uses the term "warp", it is something with tinges of science fiction, but pre-Star trek, a kind of sudden contortion.

And this brings us to another problem of radical cultural specificity: when is something actually culturally specific, and when is it textually or individually specific to a particular fictional character? Nobody but Cú Chulainn appears to experience the ríastrad. Indeed, one of the names that is used for him is "in ríastarthae" — the distorted or warped one - and it is used for nobody else. At what point do we abandon the notion that this is something that is culturallyspecific and embrace the idea that it is so specific that it does not need to remain tied to its culture? Aixelá offers no particular strategy that can account for taking a culturally-specific item and creating a completely new concept in the target culture to account for it. But with a concept that is used in such a limited way, and that does not have clear connections to any other cultural items or understanding (unlike, say, the idea of salmon being fish that can jump in extraordinary ways), perhaps a new type of strategy is required.

This example suggests another area in which some kind of radical cultural specificity might exist: speculative fiction, including science fiction and fantasy. Radical cultural specificity as I have been discussing it stems from a lack of actual native participants of a culture, and the absence of additional resources beyond the text and the fixed and limited system of other texts from the culture, then certain kinds of speculative fiction would also qualify, although at one remove, as the fictional remote culture is already mediated for the reader by the language and 
culture of writing. ${ }^{13}$ Although a culturally specific item from an alien or future culture may be as opaque to the reader as the "ox with its thick neck-rings," with no way to consult a "native" participant of the culture, the representation of that culture in a source text is carried out in a text written with the understanding that invented culturally-specific items will be unknown to the reader.

This lack of knowledge can even be played with by creators, as in the movie Demolition man (Brambilla 1993), for example, where the people of the near future (2032) no longer use toilet paper, but rather have some (never explained) system involving seashells. Sylvester Stallone's character, recently released (unfrozen) from a "cryo-prison" where he was incarcerated in 1996, is the butt of several jokes regarding his lack of knowledge about how to use the "three seashells" that have replaced toilet paper, but of course the viewer has just as little idea about them as Stallone's character. Here, like with the ox, the words themselves are not problematic; it is their role in the culture that is opaque. Given their function in the script, it may be that no explanation of them actually exists, even in the minds of the creators. The translation of these seashells in subtitles, then, presents no particular difficulty, as there is no need to tie them to any particular real-world reality; their function in both world-building (distinguishing the

\footnotetext{
${ }^{13}$ I began thinking along these lines partly because of a conversation with Ruijie Xie, a former student on the MA and in Translation and Interpreting Studies and current PhD student at the University of Manchester, who observed then and in his resulting coursework that science fiction raises the problem in translation that culture specific items may belong neither to the source nor the target culture.
} 
future from the present) and creating humor is not in any way dependent on an understanding of their actual (fictional) use. ${ }^{14}$

We might see the ríastrad of Cú Chulainn not simply as an item of radical cultural specificity, but an instance where invented cultural specificity came to be a culturally specific item in the culture hosting the invention. In a similar way, the warp-drive of Star trek or the Hulk in Marvel comics begin as an invented item and become a part of the host culture inasfar as they are recognizable elements of widely shared works of fiction within that culture. The dynamics here, however, are complicated enough that it would require another article to address them. These issues tie in with discussions about translation as represented in science fiction (for example Mossop 1996 and Washbourne 2015), the representation of translation more generally (see Beebee's concept of "transmesis"; 2012), and the translation of science fiction texts themselves. The migration of radical cultural specificity from factual situations to fictional ones will have to be left for another day.

\section{On strange beasts}

Regarding the initial contexts of radical cultural specificity, we thus have two new kinds of animal, in a metaphorical sense. First, whatever is described by the riastrad, the ich n-erred, and the speckled ox, and which must be named in English by the translator. And second, perhaps, an additional strategy, a radical strategy, of invention or reinvention of culturally

\footnotetext{
${ }^{14}$ This understanding of the phrase is borne out by a preliminary investigation of translation strategies in Czech, French, German, Italian, Polish, Portuguese, and Spanish, all of which involve a relatively straightforward translation of "three seashells" (Brambilla 1993)
} 
specific items in translation, the process of re-naming whatever has been identified. Given that we have been lurking in the Middle Ages for this exploration of cultural specificity, and thinking quite a bit about animals, it is worth closing with a brief reflection, still on things known and unknown, but focusing on other ways of knowing and picturing animals.

In our examples up to now, we have seen a range of situations, from a phrase that is almost completely opaque apart from the meanings of individual words, and in which there is not even any real contextual help to give clues about broader meanings, to an event or attribute that has a lengthy description of it, as well as metaphorical connections to more easily-parsed meanings of the word. My notion of "radical" has hinged here on the absence or impossibility of additional explanation or the absence of cultural connections, as Quine's focused on the absence of intermediaries to help with communication. It is important to note, however, as we saw with the ríastrad, that even explanations do not bridge all radical gaps. One of the most delightful demonstrations of this, I think, can be found in the medieval bestiaries: encyclopedic works describing various animals and often representing them with illustrations. The descriptions are often ludicrous; the animals are often mythical. But even when the makers of a bestiary hit upon a real animal, say an elephant or a crocodile, and clearly know things about them (elephants have trunks and tusks, four feet, tails, and apparently castles full of armed warriors on their backs), the pictures that they drew are sometimes only barely recognizable. ${ }^{15}$ Shakespeare touches on this to some extent in Antony and Cleopatra, when, asked to describe a crocodile, Antony begins his reply by observing that "It is shaped, sir, like itself, and it is as broad as it hath breadth. It is just

\footnotetext{
${ }^{15}$ For some examples, see Badke (2010), an online compilation of information from medieval bestiaries and images of animals.
} 
so high as it is, and moves with its own organs" (II.vii.39-40). Description is not necessarily enlightening.

Even with a description, someone will not necessarily draw a particularly accurate picture of something concrete. I started by suggesting that in general, we are expected to know what things mean in a particular language before we translate them. We saw some of what might happen when some things from a distant culture are unknown — words and meanings in Quine's radical translation, ideas or connections in the translation of inaccessible culturally specific items. We saw some ways of getting around lack of knowledge, using context and collocation to substitute for native speakers of the language and native participants in the culture, but even so, it is clear that the range of strategies proposed by Aixelá (1996) for translating culture-specific items is not fully available here. At the same time, perhaps even because of the distance, we also saw that some additional strategies are available, even when (or perhaps especially when) cultural specificity is accompanied by description.

Where does this leave us with relation to radical cultural specificity and translation? First, it leaves us with a need to determine not only the limits of mutual cultural comprehensibility, but also the limits of even basic knowledge of the other culture. Second, it opens up new possibilities of neologism and invention as strategic ways of dealing with either a lack of knowledge or a need to connect items with a new culture. Third, it has the potential to connect the conceptual issue of lost or forgotten cultural specificity with invented cultural specificity by observing similarities and differences in patterns of translation and knowledge. In thinking about cultural specificity, then, we may also want to determine to what extent the specificity under consideration is accessible, and in what ways, as this can limit (or expand) the repertoire of solutions available in translation. 


\section{Acknowledgments}

My thanks to Matthieu Boyd for his review and revision of my translations of and comments on Old Irish and Middle Welsh, and for the references to the speckled ox in the Triads (note 1) and to the modern description of a salmon leap that he had found. Needless to say, any remaining inaccuracies in my translations or discussion of these texts are my own.

\section{References}

Aixelá, Javier Franco. 1996. “Culture-specific items in translation.” In Translation, power, subversion, ed. by Román Álvarez and M. Carmen-África Vidal. Clevedon: Multilingual Matters, 52-78.

Badke, David. 2011. The Medieval bestiary. http://bestiary.ca/. Last accessed 3 July 2019.

Beebee, Thomas. 2012. Transmesis: Inside translation's black box. New York: Palgrave Macmillan.

Birnie, John. 1838. Account of the families of Birnie and Hamilton of Broomhill, ed. by William B. Turnbull. Edinburgh: Printed for Private Distribution.

Boyd, Matthieu. 2016. “On not eating dog.” In Ollam: Studies in Gaelic and related traditions in honor of Tomás Ó Cathasaigh, ed. by Matthieu Boyd. Madison, NJ: Fairleigh Dickinson University Press, 35-46.

Brambilla, Marco (dir.). 1993. Demolition man. Warner Brothers. DVD. Distrib. Warner Home Video Española. Region 2. Release date 1 December 2006. 
Bromwich, Rachel (ed. and trans.). 2014. Trioedd ynys Prydein: The Triads of the island of Britain. 4th edition. Cardiff: University of Wales Press.

Cassin, Barbara (ed.). 2014. Dictionary of untranslatables. trans. by Stephen Rendall, Christian Hubert, Jeffrey Mehlman, Nathanael Stein, and Michael Syrotinski, ed. by Emily Apter, Jacques Lezra, and Michael Wood. Princeton: Princeton University Press.

Davis, Craig. 2005. “The Earliest Arthurian poems in Welsh.” Metamorphosis, 13(2): 128-141. Dictionary of the Scots language. n.d. http://www.dsl.ac.uk/. Last accessed 3 July 2019. Electronic dictionary of the Irish language. n.d. www.dil.ie. Last accessed 3 July 2019. Hammond, Dick. 1999. Haunted waters: Tales of the old coast. Madeira Park, B.C.: Harbour. Haycock, Marged (ed. and trans.). 2007. Legendary poems from the Book of Taliesin. Aberystwyth: CMCS Publications.

Henry, P.L. 1982. "Furor heroicus.” Zeitschrift für celtische Philologie 39: 235-242. DOI: 10.1515/zcph.1982.39.1.235

Holmes, James S. 1994a. “The Cross-temporal factor in verse translation.” In Translated! Papers on literary translation and translation studies. 2nd ed. Amsterdam: Rodopi, 35-44.

—. 1994b. "Rebuilding the bridge at Bommel: Notes on the limits of translatability." In Translated! Papers on literary translation and translation studies. 2nd. ed. Amsterdam: Rodopi, 45-52.

Kinsella, Thomas (trans.). 1969. The Táin. Oxford: Oxford University Press.

Leslie, Jhone. 1888. The Historie of Scotland: Wrytten first in Latin by the most reuerend and worthy Jhone Leslie... and translated in Scottish by Father James Dalrymple... in... 1596. Vol I. Edinburgh: William Blackwood \& Sons. 
Loomis, Roger Sherman. 1941. “The Spoils of Annwn: An early Arthurian poem.” PMLA 56(4): 887-936.

Mannheim, Bruce. 2015. “All translation is radical translation.” In Translating worlds: The Epistemological space of translation, ed. by William F. Hanks and Carlo Severi. Chicago: Hau Books. 199-219.

Meyer, Kuno (trans.). 1888. “The Wooing of Emer.” Archaeological review 1(1-4): 68-75, 150155, 231-235, 298-307. jstor.org/stable/24707789; jstor.org/stable/24708382; jstor.org/stable/24708442; jstor.org/stable/24708716

— (ed. and trans.). 1890. "The Oldest version of Tochmarc Emire." Revue celtique 11: 433-57.

— (ed. and trans.). 1904. "Death of Connla." Ériu 1: 113-121. jstor.org/stable/30007938

Moore, Elizabeth. 2009. “'In t-indellchró bodba fer talman’: A Reading of Cú Chulainn’s first recension 'ríastrad." Proceedings of the Harvard Celtic Colloquium 29: 154-176. jstor.org/stable/41219639

Mossop, Brian. 1996. "The Image of translation in science fiction \& astronomy." The Translator 2(1): 1-26. DOI: 10.1080/13556509.1996.10798961

O’Rahilly, Cecile (ed. and trans.). 1967. Táin Bó Cúailnge from the Book of Leinster. Dublin: Dublin Institute for Advanced Studies.

Quine, W.V.O. 1959. "Meaning and translation.” In On Translation, ed. by Reuben Brower. Cambridge, MA: Harvard University Press. 148-172.

-. 1960. Word and object. Cambridge, MA: The Technology Press of the Massachusetts Institute of Technology.

Shakespeare, William. 1997. Antony and Cleopatra. New York: W.W. Norton. 
Strachan, John and J.G. O'Keeffe (eds). 1912. The Táin Bó Cúailnge from the Yellow Book of Lecan. Dublin and London: Royal Irish Academy.

Tymockzo, Maria. 1999. Translation in a postcolonial context. London: Routledge.

Van Hamel, A.G. (ed.). 1978. Compert Con Culainn. Dublin: Dublin Institute for Advanced Studies.

van Zanten, Arwen. 2007. "Going berserk: In Old Norse, Old Irish and Anglo-Saxon literature." Amsterdamer Beiträge zur älteren Germanistik 63: 43-64. DOI: 10.1163/9789401204835_007

Venuti, Lawrence. 1992. Rethinking translation: Discourse, subjectivity, ideology. London: Routledge.

—. 1995. The Translator's invisibility. London: Routledge.

Washbourne, Kelly. 2015. "The Outer limits of otherness: Ideologies of human translation in speculative fiction.” Translation studies 8(3): 284-301. DOI: 10.1080/14781700.2014.931817

Windisch, Ernst (ed.). 1880. Irische Texte mit Wörterbuch. Leipzig: Hirzel.

Wright, Crispin. 2017. "Indeterminacy of translation.” In A Companion to the philosophy of language, 2nd ed., ed. by Bob Hale, Crispin Wright, and Alexander Miller. Wiley Online Library. DOI: 10.1002/9781118972090.ch26

\section{Appendix}

Examples 1-7: "ich n-erred" with "foceird" and variants ${ }^{16}$

\footnotetext{
${ }^{16}$ In all of the transcriptions that follow, I have eliminated typographical marks indicating expanded or hypothesized letters, as the aim in presenting these examples is not philological. I have, however, left marks of length as they are
} 
(1) from Fled Bricrend (The Feast of Bricriu)

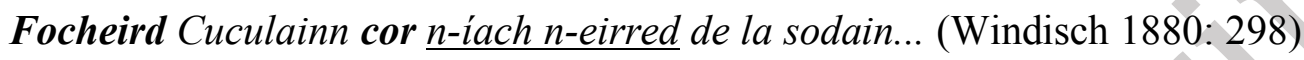

lit. Cú Chulainn ${ }^{17}$ performed the performing of the salmon of the warrior from him ${ }^{18}$ then.

(2) from Tochmarc Emire (The Wooing of Emer)

Focerd ich n-erred n-idnae, immad cless comluith, úasa erred óencarpait. (Van Hamel 1978: 25)

lit. $[\mathrm{He}]$ performed the salmon of the warrior of weapons, along with swift feats, above/upon his warrior's single chariot.

(3) from Tochmarc Emire (The Wooing of Emer)

ní ticfedsi lemse conid rolainnsi ich n-erred dím tar na trí lissu dia saigidsi... (Van Hamel 1978: 42)

in the various sources. I have standardized names as well. It should be observed further that although the focus here is on one particular phrase and its use, this by no means should be taken as indicating that the rest of the sentences are unproblematic in terms of translation. The translations are, as with Quine's radical translations, approximations. ${ }^{17}$ I am standardizing the name where it appears for convenience.

${ }^{18}$ In this example as well as examples 3-7, the phrase "ich n-erred" appears to be followed by the preposition "de" with suffixed pronouns: "de" (from him) or "dím" (from me). I interpret these to mean that the subject (which corresponds in all cases to the pronoun) is essentially performing the feat from his own starting point. 
lit. she would not come with me unless I performed the salmon of the warrior from me across the three stockades/ramparts to her reaching (i.e. to reach her).

(4) from Tochmarc Emire (The Wooing of Emer)

Ríastarthae iarom imbe $7^{9}$ saltrais for cend in drochit 7 dobeir cor $n$-iach $n$-erred de co tarla fora medon... (Van Hamel 1978: 50)

lit. It became distorted then around him $\&$ he jumped upon the head of the bridge $\&$ he did the performing of the salmon of the warrior from him so he came upon its middle...

(5) from Tochmarc Emire (The Wooing of Emer)

Dobert íarom in ingen comairli do Choin Chulainn dia tres laí, má bu do dénum láechdachta doluid, ara téised dochum Scáthaige co magin i mbai oc forcetal a dá mac .i. Cúar 7 Cett, arin corad ích n-erred de isin iburdoss mór i mbaisi fóen and. (Van Hamel 1978: 51)

lit. The girl then brought counsel to Cú Chulainn on the third day, if it were for doing of valor that he had come, that he should go to Scathach to the place where she was at the teaching of her two sons, Cúar \& Cett, that he should perform the salmon of the warrior from him into the big yew-tree in which she was reclining there.

(6) from Tochmarc Emire (The Wooing of Emer)

\footnotetext{
${ }^{19}$ This symbol is the Tironian "et" and is used throughout both medieval and modern Irish and other Gaelic languages in place of the ampersand.
} 
Airigisseom aní sin 7 foceird ích $n$-erred de súas doridisi 7 benaid a cend den chaillig. (Van Hamel 1978: 56)

lit. He himself noticed that [i.e. what she had just done] \& performed the salmon of the warrior from him up again \& struck off her, the hag's, head.

(7) from Tochmarc Emire (The Wooing of Emer)

Ráinicseom tráth rátha Forgaill 7 foceird ich n-erred de tarsna trí lissu co mbai for lár in dúnaid... (Van Hamel 1978: 63)

lit. He came then to Forgall's fort \& performed the salmon of the warrior from him across the three stockades/ramparts so that he was on the ground/in the middle of the stronghold.

Example 8: "ich n-erred" with "imbert" (as part of a list)

(8) Táin bó Cúailnge (The Cattle Raid of Cooley) (Yellow Book of Lecan version)

Bai Cüchulaind oc imbirt cles isind üarsin itir ubull-c[h]leas $7 .$. 7 7 ith nerrath $7 .$.

(Strachan and O'Keeffe 1912: 55)

lit. Cú Chulainn was at the performing of feats at that time, including the apple-feat $\&$...

$\&$ the salmon of the warrior $\&$....

Examples 9-10: "ich n-erred" in lists of feats

(9) Táin bó Cúailnge (The Cattle Raid of Cooley) (Book of Leinster version) 
Dochúaid Cú Chulaind trá for a chlessaib co mmoch in lá sain. At eat a n-uli anmand i. ubul[l]chless 7... 7ích n-errid 7... (O’Rahilly 1967: 50)

lit. Cú Chulainn came then at his feats early that day. And all their names [i.e. of the feats] are namely the apple-feat $\& \ldots \&$ the salmon of the warrior $\& \ldots$

(10) Tochmarc Emire (The Wooing of Emer)

Ó ro scáich íarom do Choin Chulainn lánfoglaim in millti do dénum la Scáthaig--etir ubalchless 7... 7ich n-erred 7... (Van Hamel 1978: 56)

lit. When had come to an end then for Cú Chulainn the whole learning of warfare [that was] for doing with Scáthach--including the apple-feat $\&$... \& the salmon of the warrior $\& \ldots$

Example 11: "ich n-erred" with "cen" (without)

(11) Aided Óenfir Áife (The Death of Áife's Only Son)

Comlaus cáinsreth saigthin ar cleitinib cíanaib cen ích n-errad n-aile. (Van Hamel 1978:

lit. I collected a beautiful flight of birds by attacking them with far[-flying] little spears without the salmon of the warrior besides. ${ }^{20}$

\footnotetext{
${ }^{20}$ I rely for much of this translation on Van Hamel's glosses on the following words: sreth, saigthin, and eó.
} 
Mailing address:

Anna Strowe

University of Manchester

Languages Reception, 3rd floor

Samuel Alexander Building

Oxford Road

Manchester

M13 9PL

United Kingdom

Anna Strowe is a lecturer in translation and interpreting studies at the University of Manchester. Her research interests include translation theory, media studies, and medieval literature. Her current research focuses on translation studies and book history, but she has published on early modern printing, power and translation, and translation theory pedagogy as well.

anna.strowe@manchester.ac.uk

http://orcid.org/0000-0002-9749-5921 